\title{
ENHANCING CREATIVITY AND PROBLEM SOLVING SKILLS THROUGH CREATIVE PROBLEM SOLVING IN TEACHING MATHEMATICS
}

\author{
Madihah KHALID (D) ${ }^{1}$, Supiah SAAD ${ }^{1}$, Siti Rafiah ABDUL HAMID (D) ${ }^{1}$, Muhammad \\ RIDHUAN ABDULLAH (D) ${ }^{1}$, Hasniza IBRAHIM (D) ${ }^{*}$, Masitah SHAHRILL (D) 2 \\ ${ }^{1}$ Department of Curriculum and Instruction, Faculty of Education, \\ International Islamic University Malaysia, P.O. Box 10, 50728 Kuala Lumpur, Malaysia \\ ${ }^{2}$ Sultan Hassanal Bolkiah Institute of Education, Universiti Brunei Darussalam, \\ Jalan Tungku Link, BE1410, Bandar Seri Begawan, Brunei
}

Received 1 August 2019; accepted 18 March 2020

\begin{abstract}
In recent years, calls to nurture and teach creativity from an early age in schools has intensified. Creativity is something regular in the teaching of arts subjects but is not a common feature in teaching science, technology, engineering and mathematics subjects. However, what really matters, is how the subject is being taught. This research aimed to foster creativity through the teaching of mathematics via problem solving that challenges the solving of problems in a creative manner, which is defined as creative problem solving. This quasi-experimental study investigates changes in students learning of mathematics via creative problem solving. Altogether, 172 Form 1 students forming treatment and comparison groups from four schools in Gombak District area, Malaysia were involved. A mixed qualitative and quantitative data were collected to investigate the effect of the 3 cycles of creative problem solving lessons implemented. Instruments used were Torrance Test of Creative Thinking, a mathematics problem solving test and creativity checklist. This paper will only present the quantitative data obtained. Results show statistically significant increases in scores for most categories of creativity and problem solving tests. This research brought together teachers and researchers in trialling creative problem solving to teach mathematics, to achieve the enhancement of students' creative thinking and problem solving skills. This coincided with the introduction of Kurikulum Standard Sekolah Menengah with new emphasis to strengthen the quality of science, technology, engineering and mathematics education in general, where higher-order thinking reforms are emphasized.
\end{abstract}

Keywords: creativity test, creativity in mathematics, enhancing problem solving ability, learning mathematics via problem solving, lesson study, new Kurikulum Standard Sekolah Menengah syllabus.

\section{Introduction}

Creativity has many meanings to different people. Some believe that it is being imaginative or inventive, while others associate creativity with original thinking or producing something that nobody has come up with before. Creativity is also related to a person's attitude. People

*Corresponding author. E-mail: hasniezaibrahim@gmail.com

This is an Open Access article distributed under the terms of the Creative Commons Attribution License (http://creativecommons. $\mathrm{org} / \mathrm{licenses} / \mathrm{by} / 4.0 /$ ), which permits unrestricted use, distribution, and reproduction in any medium, provided the original author and source are credited. 
can develop a set of attitudes which may influence them into becoming creative, where they are willing to persevere and attempt their own way of accomplishing something. Robert J. Sternberg explained creativity by saying,

"Among the attitudes toward life that may generate a person's creativity is the willingness to (a) redefine problems in novel ways, (b) take sensible risks, (c) "sell" ideas that others might not initially accept, (d) persevere in the face of obstacles, and (e) examine whether their own preconceptions are interfering with their creative process" (2012, p. 5).

No matter what creativity is believed to be, it is at the foundation of innovation which is one of the vital ingredients for a country's development, especially for the knowledge-based economy. Hence, having creative workforce is important for any country to move forward. Fortunately, every person has the potential to be creative, and creativity is closely related to ideas, feelings, mind, experience and the need of an individual. Four aspects were identified in defining creativity:

"1) Interaction of aptitude, process, and environment; 2) Perceptible product, 3) Novel and useful results in new and useful identifiable product for society and 4) Social context" (Plucker et al., 2004, pp. 90-92).

In mathematics, creativity is resulted when students conceive and create novel approaches to solving problems that are carefully planned by their mathematics teacher. Aspects of creativity that is appropriate for their level may be demonstrated as a result of their personal inquiry. In this study, the process of using creativity to produce novel solutions to the carefully planned problems is known as Creative Problem Solving (CPS). CPS has a dual role to enhance students' problem solving skills as well as their creativity. Hence, CPS skills refer to the ability of individuals to solve problems through the development of creative and brilliant ideas. The teaching strategies involve a process of reasoning that encourages students to think through critical questions and appropriate discussions. Discussions and exposure to a variety of methods can stimulate students' desire to be more creative in solving problems and motivate them to learn.

Teaching creativity is feasible in other subjects too. James (2015, p. 1032) claimed that it is possible to establish creativity-enhancing learning environment. Her paper (James, 2015, p. 1041) suggested that mind shifts, reflective and intentional practice, and renewed energy are required to create learning environment that enhance creativity successfully. Another study by Kaplan (2019, p. 145) on teaching for creativity development related how a course for trainee teachers was successful in inspiring those teacher candidates in applying and analyzing creativity theory to instruction. Hence, acknowledging the importance of creativity and viability of teaching creativity to school children, this research study was undertaken to investigate the impact of CPS in the subject of mathematics on Form 1 (Year 7) students' creativity and problem solving skills.

Isoda (2010, p. 17) claimed that problem solving approach is a consequence of lesson study in Japan since more than a century ago. It is also considered a theory of teaching for the subject of mathematics that involved inculcating self-learning for Japanese school children (Isoda, 2010, p. 17) which embrace learning how to learn. Meanwhile, Lesh and Zawojewski (2007, p. 782) clarified that learning of mathematics should be organized through problem 
solving, and proposed a shift from traditional views of problem solving to one that emphasizes, "synergistic relationships between learning and problem solving". This include:

"the process of interpreting a situation mathematically, which usually involves several iterative cycles of expressing, testing and revising mathematical interpretations - and sorting out, integrating, modifying, revising and or refining clusters of mathematical concepts from various topics within and beyond mathematics" (Lesh \& Zawojewski, 2007, p. 782).

\section{Creativity and mathematics}

\subsection{Creativity in general}

Creativity is at the foundation of innovation which is one of the vital ingredients for our country's development. Creativity is the process of having original ideas that have value (Robinson \& Aronica, 2015, p. 118), and is further divided into two concepts - putting imagination to work (creativity) and putting new ideas into practice (innovation).

Ken Robinson was quoted as famously saying that "schools kill creativity" at the official TED conference in 2006. He asserted that the school environment does not seem to favour the inculcation of creativity. This include the pedagogy applied by some teachers that do not only fail to enhance creativity, but make students uncreative, because they are not given a chance to express their creativity especially in a mathematics class. According to him (Robinson, 2006), we should also acknowledge multiple types of intelligence, and argued that the way we are educating our children should be examined, since creativity can be cultivated to produce creative students.

It is believed that creativity can be nurtured using the appropriate creative environment because interaction with the everyday creative environment is the most powerful possibility of nurturing creativity in individuals, especially in children (Mellou, 1996; Ayob et al., 2011; Trawick-Smith, 2014). Nurturing creativity in school is possible through continuous enrichment of children's environment, such as development of creative programs for creative thinking, and may be fostered across many content areas. Teachers may teach content and infuse thinking skills particularly creativity without much fuss. However, teachers need to be clear with the teaching objectives and learning outcomes. Additionally, the teachers need to identify the right type of learning activities that can be employed and participated by students (Costa, 2001, p. 246).

\subsection{Creativity in mathematics and problem solving}

Upon examining the pedagogy of teaching mathematics in many countries, it was found that mathematics is associated with rote-memorization of formulas or procedures and seat work (Novak, 2010; Greeno, 2017). Although there is a role for rote-learning, memorized knowledge is not half as useful as knowledge that is actually understood. Rote-learning makes mathematics lesson boring and led to many students hating mathematics. An article about the notion of mathematical creativity by Liljedahl and Sriraman (2006, p. 19), proposed that, mathematical creativity at the school level can be thought of as: 
1. The process that results in unusual (novel) and/or insightful solution(s) to a given problem or analogous problems, and/or

2. The formulation of new questions and/or possibilities that allow an old problem to be regarded from a new angle.

The important role of problem solving is obvious in the two statements above and creativity in mathematics can be promoted through problem solving. Ellwood, Pallier, Snyder, and Gallate (2009, p. 1) claimed that there is a great overlap between the literature on creativity and that on problem solving, while Plucker, Beghetto, and Dow (2004, pp. 83-84) consider creativity as an important component of problem solving. Chamberlin and Moon (2005, p. 38) define creativity in mathematics as an unusual ability to generate novel and useful solutions to simulated or real applied problems using mathematical modeling. Consequently, Posamentier, Smith, and Stepelman (2009, p. 121), claimed that "solving a problem is like inventing something new". The role of problem solving in promoting creativity is clear, hence students should be engaged with challenging problems and be made to experience this aspect of CPS. This research attempted to nurture creativity through mathematical problem solving, namely CPS, a problem solving approach with the emphasis on creativity. Creativity is achieved through solving problems which are open-ended and appropriate to the context of the topics chosen.

Given that creativity is teachable, we will now define creativity in school mathematics. The appropriate definition for creativity at school level is given by Sriraman (2005, p. 24) which is "The process that results in unusual and/or insightful solution(s) to a given problem or analogous problems". Meanwhile, Liljedahl and Sriraman defined mathematical creativity as:

"the ability to produce original work that significantly extends the body of knowledge which could also include significant syntheses and extensions of known ideas" (2006, p. 18).

The National Council of Teachers of Mathematics document defines problem solving in mathematics education as "engaging in a task for which the solution method is not known in advance" (2000, p. 52). In trying to execute problem solving, students must utilize their knowledge in finding a solution to a problem, a process which would lead to new discovery and mathematical understandings. On the other hand, other features that students could acquire by learning the method of problem solving in mathematics are,

"ways of thinking, habits of persistence and curiosity, and confidence in unfamiliar situations that will serve them well outside the mathematics classroom" (National Council of Teachers of Mathematics, 2000).

Problem solving is also considered as one of the most important skills in the 21 st century that a student should possess because of the many advantages that a good problem solver would enjoy in everyday life and in the workplace. Therefore, problem solving should be considered an integral part of mathematics learning and it should not be viewed as exercises that students perform at the end of every topic from the school textbook.

Observe the nature of the workforce today, and it can be seen that machines are taking over the repetitive actions in a job task. Additionally, one in ten persons encounter more complex problems that require at least 30 minutes to solve, which imply the demand for complex problem solving skills in many highly skilled managerial, professional and techni- 
cal occupations (OECD, 2014a, p. 13). Because of the importance of problem solving, Program for International Student Assessment (PISA), besides testing 15-year old students on mathematics, science and reading, also focuses testing students on problem solving. In 2003, students were given a series of paper-based exercises to test their problem solving skills. Then in 2012, computer-based and the student's interaction with the problem were introduced (OECD, 2013, p. 120). In 2012, PISA defines CPS competency as:

\begin{abstract}
"an individual's capacity to engage in cognitive processing to understand and resolve problem situations where a method of solution is not immediately obvious. It includes the willingness to engage with such situations in order to achieve one's potential as a constructive and reflective citizen" (OECD, 2013, p. 122).
\end{abstract}

Hence, teaching mathematics through problem solving is a term used to describe the method of teaching where the teaching of mathematics topics is focused through problem solving contexts and enquiry-oriented environments. This method of teaching is demonstrated by the teacher,

\begin{abstract}
"helping students to construct a deep understanding of mathematical ideas and processes by engaging them in doing mathematics: creating, conjecturing, exploring, testing, and verifying" (Lester et al., 1994, p. 154).
\end{abstract}

\title{
1.3. Problem statement
}

Malaysian 15-year old students did not score well in the PISA 2012 result for CPS. Malaysia ranked 39 out of 44 countries participating in the assessment. Our students scored 421 in mathematics and 422 in problem solving while the Organisation for Economic Co-Operation and Development averages were 511 and 500 respectively (2014c, p. 52). About half of our students were in level 1 and below in problem solving. Only about $1 \%$ was among the top performers who are able to solve the most complex problems at levels 5 and 6 while the rest are concentrated at level 2, while some at level 3 (OECD, 2014b, p. 57).

Many of the elements of teaching and learning has been identified by the Ministry of Education (Malaysia) (MEM) as initiatives to create a direct impact on the quality of education; both through student outcomes that are related to curriculum and instruction (including assessment) and teachers' teaching (2013, p. 45). However, Mathematics teaching in many schools in Malaysia can still be characterized as teacher-centred (Lim, 2010; Saleh \& Aziz, 2012). This is contrary to the recommendation by the MEM where it was already suggested in 2003 for teachers to incorporate five elements in teaching and learning mathematics - i.e. problem solving in mathematics; communication in mathematics; reasoning in mathematics; mathematical connections; and application of technology, should be the focus (Ministry of Education, Malaysia, 2003, cited in Lim, 2010, p. 4). The document further proposed a variety of other teaching approaches such as cooperative learning, contextual learning, mastery learning, constructivism, enquiry/discovery learning, etc. However, until now many teachers are still employing their traditional teaching practices or strategies and students are still learning in the way that does not mirror the recommendations given by the MEM.

The new Kurikulum Standard Sekolah Menengah (KSSM) introduced in early 2017 in Malaysia, saw changes in the mathematics syllabus (such as more topics to be taught at Form 
1 level with some topics being from higher levels before) that made the teachers unprepared and in need of help. The researchers believe that managing and coping with the syllabus can be organized via teaching through problem solving, while teachers should be given appropriate training/coaching in order to shift their way of teaching that conform to the new curriculum. Teachers need to work closely with each other to design their classroom instruction and practice what they learnt directly by trialing and examining their instructional design together. Fostering creativity can be encouraged through teaching using the problem solving approach.

\subsection{Research objectives and research questions}

This paper presents the result of a study which investigate the effect of teaching CPS in mathematics to Malaysian or Form 1 children. The main effect that was examined is the change in students' creativity, which were measured quantitatively and qualitatively. Consequently, the effect on students' ability to solve problems and the relationship between them are also examined. Any changes in students who participated in this study were documented, particularly those changes during and after going through the intervention. This study is guided by the following research questions:

1. Are there differences in children's creativity after intervention, as measured through the Torrance Test of Creative Thinking (TTCT) and observation checklist?

2. What are the changes in children's mathematical problem solving ability after intervention?

3. Is there any relationship between creativity and problem solving ability after learning through CPS?

\subsection{Theoretical and conceptual framework}

Among the attitudes toward life that may generate a person's creativity is the willingness to (a) redefine problems in novel ways, (b) take sensible risks, (c) "sell" ideas that others might not initially accept, (d) persevere in the face of obstacles, and (e) examine whether their own preconceptions are interfering with their creative process (Sternberg, 2012, p. 5). Such attitudes are teachable and can be ingrained in students through instructions that encourages them to think for themselves. Sternberg stated that

"Creativity comprises several different aspects: (a) abilities, (b) knowledge, (c) styles of thinking, (d) personality attributes, (e) motivation, especially intrinsic motivation, and (f) environment" (2006, p. 88),

and can be suppressed if a person is unwilling to take sensible risks or if he/she is not in the environment that provides at least minimal support for creativity. It is thus crucially important, especially in schools, to provide an environment that allows creativity to flourish.

One of the most common frameworks for creative thinking was developed by Torrance (1971, p. 76) with four aspects of creativity namely - fluency, flexibility, originality and elaboration. He later dropped flexibility in 1984 and added two other aspects - resistance to pre- 
mature closure and abstractness of titles in his figural test. Torrance saw creativity broadly as the process of sensing a problem, searching for possible solutions, drawing hypotheses, testing and evaluating, and communicating the results to others. He added that the process includes original ideas, a different point of view, breaking out of the mould, as well as recombining ideas or seeing new relationships among ideas. However, this research chooses the four components of creativity that Torrance (1971, p. 76) identified in his original creativity framework for mathematics problem solving in order to characterize the development of students' creative thinking. Creativity is believed to be an integral part of mathematics (Brunkalla, 2009) and has been proposed as one of the major components to be included in mathematics education, since "the essence of mathematics is thinking creatively" (Mann, 2006, p. 239).

This study proposed creativity to be fostered through CPS. Whether problem solving is creative or not depends on how it is taught and how it is learnt. Teachers' pedagogical content knowledge influences how mathematics will be taught. The problem context (environment whether it will be personal or social learning, teacher-centred or student-centred, interactive etc.) or the nature of tasks (problem type - whether open ended, static, dynamic, ill-defined) determine the success of CPS. On the other hand, the process of learning (in this case problem solving), is made up of the following sequence: exploring and understanding, representing and formulating, planning and executing, and finally monitoring and reflecting (OECD, 2014c) which is comparable to Polya (2004), a classic which was used in the framework of this study (refer to Figure 1).

The middle part of the framework shows mutual relationship between CPS and creativity. The components of creativity that were examined in this study are the combination of Torrance (1971) and Guilford (1967, pp. 10-11) model - fluency, flexibility, originality and elaboration. Fluency is the ability to generate quantities of ideas, flexibility is the ability to create different categories of ideas from different points, originality is the ability to create new and unique ideas and finally, elaboration is the ability to expand on an idea. Meanwhile, three problem solving criteria were emphasized so that CPS could be generated. The first criterion is the process of problem solving, where a 4-step process by Polya (2004, p. 41) in guiding students to solve problems was adopted. The second and third criteria of CPS are the learning context and nature of problem. The learning context here means students setting which are characterized by student-centred and collaborative group-work learning, where social interaction and negotiation of understanding with others can help students to construct knowledge.

Additionally, the nature of problems describes the kind of problems that were posed during CPS which are open-ended, authentic and dynamic. Authentic problems provide realistic contexts that provide for construction of knowledge. In order to generate creativity in problem solving, the problems created should be open-ended where multiple solutions (answers and/or methods) is possible. Dynamic here means the problems created and posed should create a lively environment where students would be discussing or debating their solutions. Finally, lesson study will help the teachers to come up with criteria 2 and 3. However, this paper will only report the middle part, which is on creativity and problem solving and the relationship between them, and not the lesson study part. 


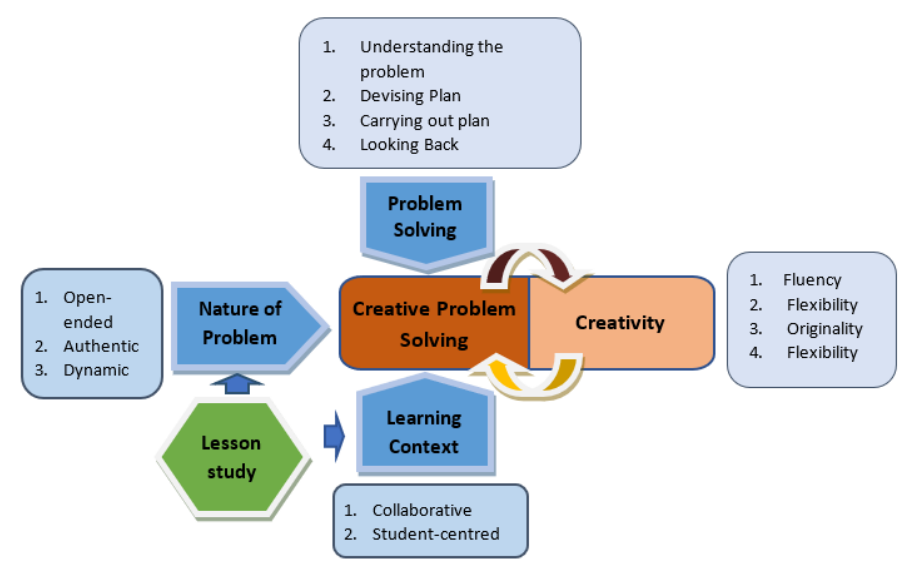

Figure 1. The conceptual framework of the research (source: created by authors)

\section{Methodology}

A mixed qualitative and quantitative methodology was adopted for this study. The study investigates changes in students' creativity after being taught mathematics via the collaborative, CPS way. The design of this study is closer to a mix of one-shot and static-group pre-experimental design. Although comparison group is present, they are not considered as control group in the pure sense. Four existing classes went through intervention lesson while three other groups (supposedly 4) acted as comparison groups. The groups were not rearranged to be equal for serving the purpose of experimental and comparison group as in the real sense of quasi-experimental design study. Although there are drawbacks to this design, it is felt that this design is more ethical and non-disruptive in nature because classes are not rearranged to produce almost equal experimental and control group as in pure quasiexperimental design. The main result to determine the success of the intervention would be based on the increase in marks from pre- to post-test. The use of comparison group is only to confirm if the changes is due to the intervention.

\subsection{Population and sample}

The sample for this study consists of 172 students, chosen based on purposive sampling, a non-probability sample that is selected based on characteristics of a population and the objective of the study. The number of students for each school and class is shown in Table 1. 
Table 1. The sample of the study (source: created by authors)

\begin{tabular}{|l|l|c|c|c|c|}
\hline \multicolumn{2}{|c|}{} & \multicolumn{2}{c|}{ Treatment } & \multicolumn{2}{c|}{ Comparison } \\
\hline \multirow{2}{*}{ School } & Gender & Number & $\%$ & Number & $\%$ \\
\hline \multirow{3}{*}{ SMKSS } & - Male & 10 & 9.6 & - & - \\
\cline { 2 - 6 } & - Female & 7 & 6.7 & - & - \\
\hline \multirow{3}{*}{ SMKTS } & - Male & 13 & 12.5 & 11 & 16.2 \\
\cline { 2 - 6 } & - Female & 12 & 11.5 & 5 & 7.3 \\
\hline \multirow{3}{*}{ SMKHC } & - Male & 9 & 8.7 & 12 & 16.6 \\
\cline { 2 - 6 } & - Female & 15 & 14.4 & 9 & 14.3 \\
\hline \multirow{3}{*}{ SMKSG } & - Male & 21 & 20.2 & 17 & 25.0 \\
\cline { 2 - 6 } & - Female & 17 & 16.4 & 14 & 20.6 \\
\hline \multirow{2}{*}{ Total } & - Male & 53 & 51.0 & 40 & 58.8 \\
\cline { 2 - 6 } & - Female & 51 & 49.0 & 28 & 41.2 \\
\hline Grand total & & 104 & 100 & 68 & 100 \\
\hline
\end{tabular}

Typical case purposive sampling as is applied here, is a type of purposive sampling that is useful when a researcher wants to study a phenomenon or trend as it relates to what are considered "typical" or "average" members of the effected population. The sample schools chosen satisfy certain criteria, that is: average schools, students with average ability in mathematics measured through Primary School Evaluation Test (Malaysia) result and participating teachers having about 5 years teaching experience. All four schools are normal, semi-urban public schools. For interview purposes, six students from each school were randomly selected to participate in the focus-group interview in order to find out their opinions.

\subsection{Instruments}

Different instruments were employed to collect data for this study. The instruments were the TTCT (pre- and post-tests) and problem solving (pre- and post-tests), and the interview protocol for students. Meanwhile, researchers' field notes, students' work and video recordings of all lessons and reflection stages were also used to supplement any missing links when the situation warrants them. In fact, all activities associated to this study were video-recorded.

\subsubsection{Torrance Tests of Creative Thinking - pre- and post-}

The TTCT that was used in this study is the figural version which requires students to complete and give titles to the picture that they created, given very minimal sketches (lines or circles etc.) to start. The highly reliable tests are the most widely used tests of its kind and have been used for identification of the creatively gifted. It comes complete with instruction and marking scheme as well as means and standard deviations according to grade-level and age-level. Both the pre- and post-forms were utilized. The test was administered by the teachers at the school by adhering strictly to the instructions of the researchers. The pre-test was given out one week before the start of intervention while the parallel post-test was given after one week of intervention. 


\subsubsection{Observation checklist}

Although the whole process involved in the study was videotaped, a checklist was prepared to be used for classroom observation by teachers and observers. It contains 6 items each for the four domains of creativity i.e. fluency, flexibility, originality and elaboration. Observers observed how students solve problems that are discussed in the class (during the lesson) and tick the appropriate columns of options according to their judgement upon observing the students.

\subsubsection{Problem solving test - pre- and post-}

The tests were created based on the PISA 2012 mathematics questions. Six questions were carefully selected for each test that were developed in parallel, so that they are appropriate for the age group of the Form 1 students which is approximately 13 years old. Therefore, the difficulty level of the test selected was only at proficiency level 3 since the original test paper was created for 15-year-old students as PISA originally intended. Instructions were given to the teachers to administer the pre- problem solving test one week before the intervention and one week after the intervention for the post-test. Teachers were reminded that they should not give this test on the same day as TTCT to avoid students being too tired mentally.

\subsection{Instrument validity and reliability}

The TTCT and PISA problem solving questions which was adopted in this study has reported very high reliability and validity globally. Therefore, no pilot study was done on them. However, since the interview protocol are newly created, a pilot study was done to test the instrument. The TTCT was reviewed four times since it was developed by Torrance in 1966 . According to the TTCT manuals of 1966 and 1974, the range of the test-retest reliability coefficients is .50 to .93 . However, after a few revisions, the reliability estimates of the creative index ranged between .89 and .94 (Kim, 2006, p. 6), which is way greater than the desired 0.70 level. Although only certain questions from PISA 2012 were used in this research study, the reliability of PISA problem solving questions of 2012 were reported to be 0.88 (OECD, 2014d). However, the reliability and validity tests were performed on the pre- and post-test scripts of both tests and the result is in Table 2.

Table 2. Internal reliability and eta-squared value of the instrument (source: created by authors)

\begin{tabular}{|c|c|c|c|c|c|c|c|c|}
\hline \multirow{3}{*}{ Instrument } & \multirow{3}{*}{\multicolumn{2}{|c|}{$\begin{array}{l}\text { Reliability } \\
(\alpha)\end{array}$}} & \multicolumn{4}{|c|}{ Inter-item correlation } & \multirow{2}{*}{\multicolumn{2}{|c|}{$\begin{array}{l}\text { Analysis of variance } \\
\qquad(\eta 2)\end{array}$}} \\
\hline & & & \multicolumn{2}{|r|}{ Pre- } & \multicolumn{2}{|c|}{ Post- } & & \\
\hline & & & Mean & Range & Mean & Range & Pre- & Post- \\
\hline $\begin{array}{l}\text { Torrance Test of } \\
\text { Creative Thinking }\end{array}$ & $\begin{array}{l}.913 \\
.923\end{array}$ & & .569 & $.149-.950$ & .598 & $.224-.948$ & $9.917^{\star *}$ & $8.795^{\star *}$ \\
\hline $\begin{array}{l}\text { Problem solving } \\
\text { test }\end{array}$ & .615 & .610 & .212 & $.108-.413$ & .188 & $.268-.398$ & $10.495^{\star *}$ & $25.508^{\star \star}$ \\
\hline
\end{tabular}

$\left.{ }^{* *} \mathrm{p}<0.01\right)$. 
The Cronbach's alpha of TTCT shows a very high reliability while the reliability for the problem solving test is only at an acceptable level since it is between 0.6 and 0.7 with small sample (Griethuijsen et al., 2014, p. 588). The mean for inter item correlation were in the acceptable range of $0.15-0.50$ while the values of correlation are somewhat in acceptable range of .15 and .85 for problem solving test but a bit high for TTCT. The eta-squared values show that the instruments are able to differentiate between the sample of different schools.

The observation checklist shows good reliability for all of the four constructs of originality, elaboration, fluency and flexibility at $0.893,0.922,0.894$ and 0.938 respectively. The pattern matrix confirmatory factor analysis shows two constructs of originality and elaboration loading perfectly into two columns while one item from flexibility overlaps in fluency which otherwise behaves accordingly. Hence the instruments are quite reliable and valid for use in this study. A summary of research objectives, research questions, data type and collection strategy, sampling and sample, validity criteria addressed, and data analysis executed in this study is presented in the Appendix.

\section{Results}

The findings for this research will be presented according to the research questions. The quantitative findings will be presented first, followed by the qualitative findings.

Answering research question 1 - determining students' creativity as measured by the creativity test.

Table 3 shows the result from the four different schools. It can be observed here that the data were obtained only from 106 students where 90 were in the treatment group and another class of 16 in the comparison group. The number of creative students increased from

Table 3. The number of creative children (pre- and post-intervention) from both the treatment and the comparison group (source: created by authors)

\begin{tabular}{|c|c|c|c|c|c|c|c|}
\hline \multirow{2}{*}{ School } & \multirow{2}{*}{ Gender } & \multicolumn{3}{|c|}{$\begin{array}{c}\text { Treatment } \\
\text { Number of creative }\end{array}$} & \multicolumn{3}{|c|}{$\begin{array}{c}\text { Comparison } \\
\text { Number of creative }\end{array}$} \\
\hline & & & pre- & post- & & pre- & post- \\
\hline \multirow[t]{2}{*}{ SMKSS } & - Male & 7 & 2 & 5 & & & \\
\hline & - Female & 7 & 2 & 6 & & & \\
\hline \multirow[t]{2}{*}{ SMKTS } & - Male & 14 & 0 & 10 & 11 & 5 & 6 \\
\hline & - Female & 11 & 3 & 8 & 5 & 0 & 1 \\
\hline \multirow[t]{2}{*}{ SMKHC } & - Male & 9 & 1 & 6 & & & \\
\hline & - Female & 13 & 0 & 9 & & & \\
\hline \multirow[t]{2}{*}{ SMKSG } & - Male & 15 & 0 & 2 & & & \\
\hline & - Female & 14 & 0 & 1 & & & \\
\hline \multirow[t]{2}{*}{ Total } & - Male & 44 & 8 & 23 & 11 & 5 & 6 \\
\hline & - Female & 46 & 5 & 24 & 5 & 0 & 1 \\
\hline \multicolumn{2}{|c|}{ Grand total } & 90 & 13 & 47 & 16 & 5 & 7 \\
\hline
\end{tabular}

Note: if the creativity index score is 100 and above, students are considered creative. 
13 to $47(262 \%)$ in the treatment group as compared to an increase from 5 to 7 (40\%) from the comparison group. Using the marks as scored from the creativity index and satisfying the condition of significant correlation between the pre- and post-, paired sample t-test was executed (Table 4). The result in Table 3 shows a significant difference between the post- and pre-creativity index for the treatment group. This suggests that the intervention has led to significant increase in students' creativity.

Analysis of covariance (ANCOVA) was also executed for the creativity index data (it satisfies the condition for fairly similar values for the pre TTCT between treatment and comparison group and the homogeneity of regression). The result shown in Table 5 is not statistically significant. Hence, we cannot assume that the difference between the marks from the pre and post-test is due to the intervention. However, as a note of caution; this test was performed with very small sample in the comparison group. Hence, although the result seems to suggest that the intervention did not affect students' performance in creativity, we need to be careful when conclusion is being made. The R-Squared seems to suggest that the treatment affect only $9.1 \%$ on the performance.

Table 4. Paired sample t-test comparing post- and pre-test scores in creativity (treatment and comparison group) (source: created by authors)

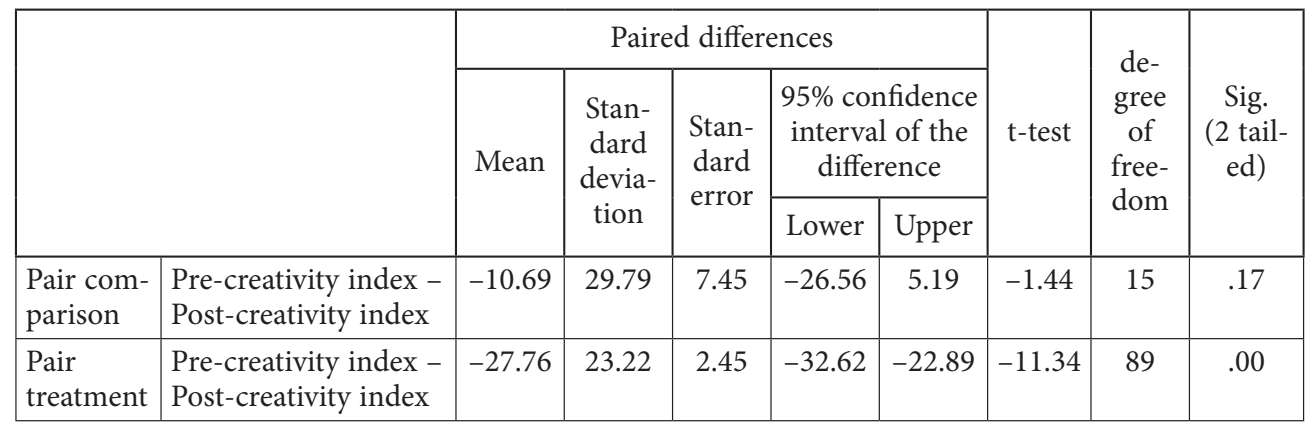

Table 5. Analysis of covariance testing the significance of the intervention (treatment and comparison group) (source: created by authors)

\begin{tabular}{|l|c|c|c|c|c|c|}
\hline \multicolumn{7}{|c|}{ Dependent variable: Creativity Index B } \\
\hline Source & $\begin{array}{c}\text { Type III sum } \\
\text { of squares }\end{array}$ & $\begin{array}{c}\text { Degree of } \\
\text { freedom }\end{array}$ & $\begin{array}{c}\text { Mean } \\
\text { square }\end{array}$ & F-test & Significant & $\begin{array}{c}\text { Partial eta } \\
\text { squared }\end{array}$ \\
\hline Corrected model & $4140.412^{\mathrm{a}}$ & 2 & 2070.206 & 6.252 & .003 & .108 \\
\hline Intercept & 41161.480 & 1 & 41161.480 & 124.306 & .000 & .547 \\
\hline Creativity Index A & 4135.745 & 1 & 4135.745 & 12.490 & .001 & .108 \\
\hline Group & 239.731 & 1 & 239.731 & .724 & .397 & .007 \\
\hline Error & 34106.494 & 10 & 331.131 & & & \\
\hline Total & 1237758.000 & 106 & & & & \\
\hline Corrected total & 38246.906 & 105 & & & & \\
\hline
\end{tabular}

a. R-Squared $=.108$ (adjusted R-Squared $=.091)$ 


\subsection{Results of structured observation}

Table 6 shows the mean and standard deviation (SD) for each construct of creativity collected through the checklists that were completed by thirty-six observers during the intervention of cycles 1 to 3 .

The data shows that overall, students' creativity increases from moderate to high from the beginning until the completion of the project. Each construct or creativity, i.e. originality, elaboration, fluency and flexibility also increase from moderate to high from the first to the third cycle. In cycle 1, the construct of fluency gives the highest mean while the lowest mean is from the construct of flexibility. It can clearly be observed that fluency still shows the highest mean in cycles 2 and 3, while flexibility still scores the lowest mean. One-way analysis of variance was performed to investigate if the changes are significant from cycle to cycle and also according to different schools. Table 7 shows the details of the analysis for

Table 6. Items in observation checklist (source: created by authors)

\begin{tabular}{|l|c|c|c|c|c|c|}
\hline \multirow{2}{*}{\multicolumn{1}{|c|}{ Items }} & \multicolumn{2}{|c|}{ Cycle 1 } & \multicolumn{2}{c|}{ Cycle 2 } & \multicolumn{2}{c|}{ Cycle 3 } \\
\cline { 2 - 7 } & Mean & SD & Mean & SD & Mean & SD \\
\hline Originality & 2.921 & .644 & 3.272 & .773 & 3.857 & .687 \\
\hline Elaboration & 2.907 & .701 & 3.386 & .711 & 3.954 & .570 \\
\hline Fluency & 2.983 & .638 & 3.405 & .673 & 4.028 & 1.671 \\
\hline Flexibility & 2.861 & .767 & 3.241 & .639 & 3.708 & .656 \\
\hline Average score overall & 2.910 & .708 & 3.313 & .685 & 3.874 & .615 \\
\hline
\end{tabular}

Table 7. Analysis of variance for the comparison of mean in different constructs of creativity for the 3 cycles (source: created by authors)

\begin{tabular}{|c|c|c|c|c|c|c|}
\hline & & $\begin{array}{l}\text { Sum of } \\
\text { squares }\end{array}$ & $\begin{array}{l}\text { Degree of } \\
\text { freedom }\end{array}$ & $\begin{array}{l}\text { Mean } \\
\text { square }\end{array}$ & F-test & Significant \\
\hline \multirow[t]{3}{*}{ meanOri } & Between cycles & 16.083 & 2 & 8.041 & 16.182 & .000 \\
\hline & Within cycle & 53.170 & 107 & .497 & & \\
\hline & Total & 69.253 & 109 & & & \\
\hline \multirow[t]{3}{*}{ meanEla } & Between cycles & 19.755 & 2 & 9.877 & 22.350 & .000 \\
\hline & Within cycle & 47.287 & 107 & .442 & & \\
\hline & Total & 67.041 & 109 & & & \\
\hline \multirow[t]{3}{*}{ meanFlu } & Between cycles & 29.834 & 2 & 14.917 & 12.395 & .000 \\
\hline & Within cycle & 128.777 & 107 & 1.204 & & \\
\hline & Total & 158.611 & 109 & & & \\
\hline \multirow[t]{3}{*}{ meanFlex } & Between cycles & 12.967 & 2 & 6.484 & 13.669 & .000 \\
\hline & Within cycle & 50.754 & 107 & .474 & & \\
\hline & Total & 63.721 & 109 & & & \\
\hline \multirow[t]{3}{*}{ meanAll } & Between cycles & 16.888 & 2 & 8.444 & 20.804 & .000 \\
\hline & Within cycle & 43.430 & 107 & .406 & & \\
\hline & Total & 60.317 & 109 & & & \\
\hline
\end{tabular}


different cycles. It can be observed that the overall change as well as the changes in originality, elaboration, fluency and flexibility are all significant.

Answering research question 2 - whether there are any changes in students' problem solving ability.

The result from Table 8 shows a $24 \%$ increase in the post-test for the treatment group as compared to $15 \%$ increase for the comparison group. It can also be observed that there are more data from the comparison group for the problem solving test (2 classes) as compared to the creativity test (1 class).

Table 8. The marks for problem solving test of students from different schools (treatment and comparison group) (source: created by authors)

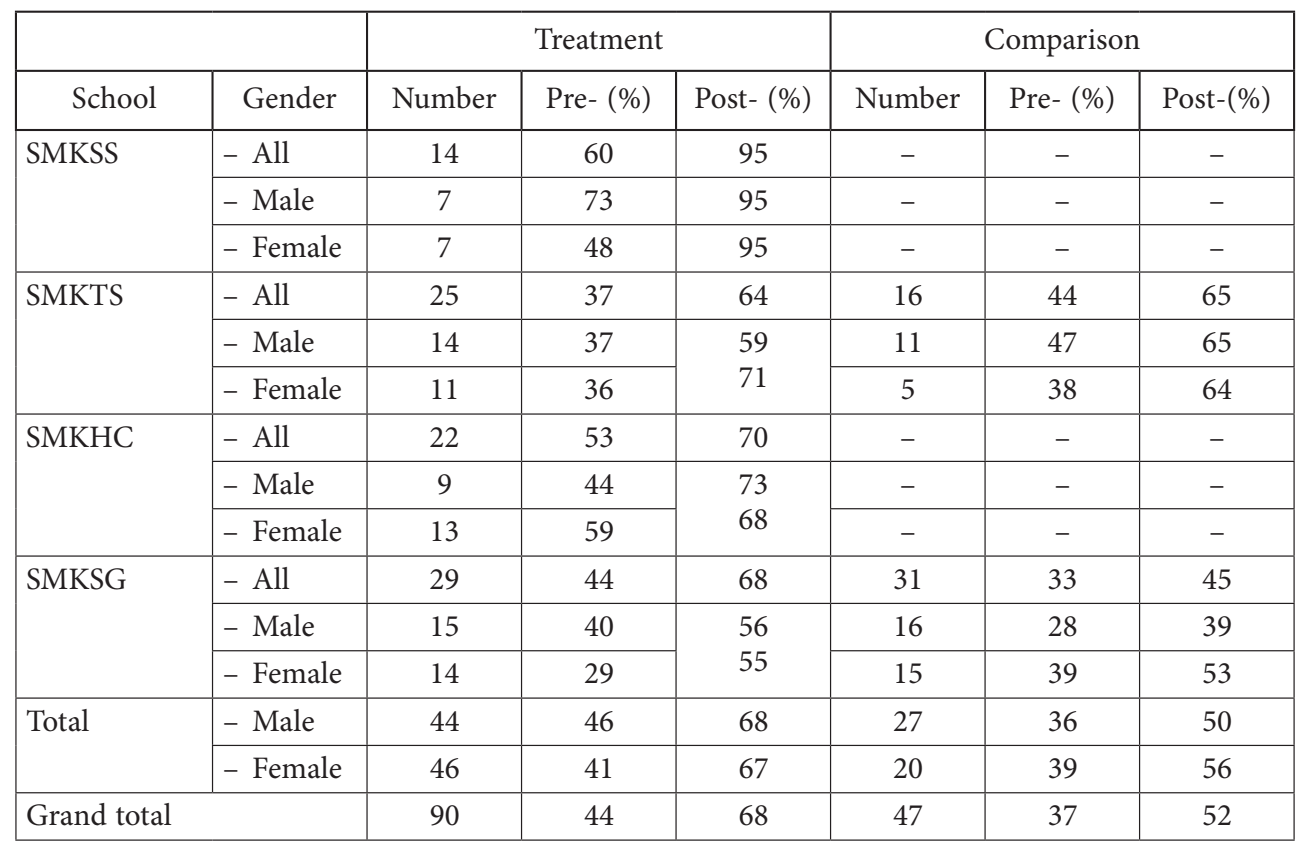

Table 9. Paired samples test for treatment and comparison group (source: created by authors)

\begin{tabular}{|c|c|c|c|c|c|c|c|c|c|}
\hline & \multicolumn{5}{|c|}{ Paired differences } & \multirow{3}{*}{ t-test } & \multirow{3}{*}{$\begin{array}{l}\text { Degree } \\
\text { of } \\
\text { Free- } \\
\text { dom }\end{array}$} & \multirow{3}{*}{$\begin{array}{c}\text { Sig. } \\
\text { (2-tailed) }\end{array}$} \\
\hline & & \multirow[t]{2}{*}{ Mean } & \multirow[t]{2}{*}{$\begin{array}{l}\text { Standard } \\
\text { deviation }\end{array}$} & \multirow[t]{2}{*}{$\begin{array}{c}\text { Standard } \\
\text { error }\end{array}$} & \multicolumn{2}{|c|}{$\begin{array}{l}\text { 95\% Confidence } \\
\text { interval of the } \\
\text { difference }\end{array}$} & & & \\
\hline & & & & & Lower & Upper & & & \\
\hline $\begin{array}{l}\text { Pair treat- } \\
\text { ment }\end{array}$ & $\begin{array}{l}\text { Percent } \\
\text { (post-, pre-) }\end{array}$ & 24.20 & 20.71 & 2.18 & 19.86 & 28.54 & 11.09 & 89 & .00 \\
\hline $\begin{array}{l}\text { Pair com- } \\
\text { parison }\end{array}$ & $\begin{array}{l}\text { Percent } \\
\text { (post-, pre-) }\end{array}$ & 15.13 & 18.74 & 2.73 & 9.63 & 20.63 & 5.54 & 46 & .00 \\
\hline
\end{tabular}


Paired t-test in Table 9 shows a statistically significant result for both the treatment and comparison groups, suggesting significant improvement in problem solving skills for both groups. Since the increase for the treatment group is larger than the comparison group, ANCOVA was run to determine if the difference is due to the intervention. The ANCOVA shows a statistically significant result suggesting that the larger increase in the treatment group may have been due to the intervention (see Table 10). The R-Squared value suggests that $27.3 \%$ of the change in problem solving marks may be attributed to the intervention.

Meaningful learning refers to how new information can be used effectively when needed. When solving mathematics problems in groups and applying the four stages of Polya problem solving (2004, p. 41), the participants were actively involved with the cognitive, affective and psychomotor domains of learning.

Answering research question 3 - is there a relationship between creativity and problem solving ability?

Table 10. Analysis of covariance on tests of between-treatment effects (source: created by authors)

\begin{tabular}{|l|c|c|c|c|c|c|}
\hline \multicolumn{7}{|c|}{ Dependent variable: percent post- } \\
\hline Source & $\begin{array}{c}\text { Type III sum of } \\
\text { squares }\end{array}$ & $\begin{array}{c}\text { Degree of } \\
\text { freedom }\end{array}$ & $\begin{array}{c}\text { Mean } \\
\text { square }\end{array}$ & F-test & $\begin{array}{c}\text { Sig. } \\
\text { nificant }\end{array}$ & $\begin{array}{c}\text { Partial eta } \\
\text { squared }\end{array}$ \\
\hline Corrected model & $15774.540^{\mathrm{a}}$ & 2 & 7887.270 & 26.546 & .000 & .284 \\
\hline Intercept & 40892.129 & 1 & 40892.129 & 137.630 & .000 & .507 \\
\hline Percent pre- & 8326.023 & 1 & 8326.023 & 28.023 & .000 & .173 \\
\hline Group & 4875.430 & 1 & 4875.430 & 16.409 & .000 & .109 \\
\hline Error & 39813.457 & 134 & 297.115 & & & \\
\hline Total & 589876.543 & 137 & & & & \\
\hline Corrected total & 55587.997 & 136 & & & & \\
\hline
\end{tabular}

a. R-Squared $=.284$ (adjusted R-Squared $=.273$ )

Table 11. Correlations between pre-Torrance Test of Creative Thinking and pre-problem solving test (source: created by authors)

\begin{tabular}{|l|l|c|c|}
\hline \multicolumn{2}{|c|}{} & Pre-creativity index & Percent pre- \\
\hline Pre-creativity index & Pearson correlation & 1 & -.058 \\
\cline { 2 - 4 } & Sig. (2-tailed) & & .586 \\
\cline { 2 - 4 } & Number & 90 & 90 \\
\hline
\end{tabular}

Table 12. Correlations between post-Torrance Test of Creative Thinking and post-problem solving test (source: created by authors)

\begin{tabular}{|l|l|c|c|}
\hline \multicolumn{2}{|c|}{} & Post-creativity index & Percent post- \\
\hline Post-creativity index & Pearson correlation & 1 & $.207^{*}$ \\
\cline { 2 - 4 } & Sig. (2-tailed) & & .050 \\
\cline { 2 - 4 } & Number & 90 & 90 \\
\hline
\end{tabular}

* Correlation is significant at the 0.05 level (2-tailed). 
Correlation analyses was performed on the creativity results and problem solving results for the children in the treatment group. The first analysis examined if there exist any correlation between the pre-tests in creativity (TTCT set A) and the problem solving before intervention. Table 11 shows a non-significant negative correlation, suggesting no relationship between students' ability in creative problem solving and creativity before intervention.

However, when correlation analysis was again performed on the post-tests results of creativity (TTCT set B) and problem solving, the figures show a statistically significant positive correlation (Table 12).

This suggest that after the intervention, there is a positive, albeit small relationship between the increase in the TTCT and the increase in post-problem solving test. Hence, students' exposure to creative problem solving may have contributed to creativity.

\section{Discussion}

The current study suggests that creative problem solving approaches improves students' creativity and support the finding by previous researchers (Teo \& Waugh, 2010; Park, 2013; Runco \& Johnson, 2002; Levenson, 2013; Fard et al., 2014). This study seems to strengthen the statement that teachers' awareness and effort in promoting creativity are able to foster creativity in students (Teo \& Waugh, 2010; Park, 2013; Levenson, 2013). The qualitative data complements this finding when students' result suggest that their creativity level increased as they get more involved in the intervention study - as can be interpreted from the observation data.

Meanwhile, the increase in students' problem solving ability coincided with Kopka (2010) and Hu's, Xiaohui's, and Shieh's (2017) findings, where they claimed that problem solving has created the foundation for a successful mathematics education, which seem to support the result of this study. This implies that having experienced the teaching and learning through collaborative CPS, their result increased in tandem. Silver $(1997$, p. 79$)$ claimed that fostering creativity strategies will enrich mathematical problem solving. This finding also supported the suggestion by some authors (Lester et al., 1994, pp. 661-662), who proposed that teaching mathematics by using a problem solving approach can help the students to develop a deep understanding of mathematical ideas. This observation is also in line with the claims by Sriraman (2004), which stated that creativity is crucial as a foundation in mathematics.

Nonetheless, even though the mean scores increased, the level of the participants' creative problem solving skill was still at a moderate level and can still be improved. The findings support the suggestions by researchers that enhancing students' mathematical creativity in a mathematics classroom also depends powerfully on the learning and interactive environments (Kaufman \& Sternberg, 2006).

Obviously, some students need special attention from teachers and being in a large classroom with the teacher-centred approach does not help. In a large classroom with students having various capabilities, teachers need to know the correct approach to accommodate them all. This research addresses this issue by prescribing a collaborative group work among the students. In his study, Haylock $(1987$, p. 72$)$ found positive impacts of creativity and creative problem solving in conducive classrooms. Therefore, it is crucial for teachers to create powerful learning (and interactive) environments (Kaufman \& Sternberg, 2006) to provide 
effective learning environments elements in fostering creativity as well as to accommodate the various needs of students.

Some participants in the study admitted that collaborative solving problems during the interventions made them feel more confident. They also added that solving problems in a group develops their potential, and some admitted that collaborative CPS made them feel that mathematics is easier and learning mathematics is enjoyable. Thus, CPS was able to assist them in overcoming the challenges of the new syllabus. These findings are in line with the recommendation by Park $(2013$, pp. 412, 416) who recommended that fostering creativity in mathematics can help students think in different ways besides enjoying learning mathematics.

The participants also admitted that they gain knowledge from their friends in the same group. They were able to check and compare their answers with other groups through an inter-group discussion. This finding supports the research done by Retalis, Katsamani, Georgiakakis, Lazakidou, Petropoulou, and Kargidis (2010). One of the participants raised that creative problem solving gives him the space to analyse and choose the best method for answering mathematics questions. His statement supports the work of Anderson, Krathwohl, Airasian, Cruikshank, Mayer, Pintrich, Raths, and Wittrock (2000, p. 208) when they claimed that creativity is a skill that could be cultivated to enhance the cognitive skills, which aims to be utilized in solving problems. These findings proved the positive impacts of creativity and creative problem solving (Haylock, 1987). It is crucial for teachers to create powerful learning and interactive environments to foster creativity (Kaufman \& Sternberg, 2006). The findings in this study also show that the recommendation from researchers who recommended problem solving as one of the solutions to many issues in mathematics classroom is valid (Kopka, 2010; Khalid, 2017).

\section{Conclusions}

In conclusions, it can be summarized that the collaborative CPS framework developed and applied to Form 1 students of this study in learning mathematics is effective. This study suggests that Form 1 students performed better after the interventions especially in terms of the problem solving skills and creativity. The students' creative problem solving and learning framework addressed the crucial basic characteristics of learning and the method employed has achieved many of the documented requirements of meaningful learning. This study also implies that mathematics is a suitable platform to foster creativity. It proved that solving problems in groups is effective in fostering creativity. Discussion among friends encouraged students to think and express their thoughts. Hence, students feel that learning mathematics is interesting, and they are more confident to solve the problems in more creative ways as many people contribute their idea into the group and not only focus on one solution. To conclude, the findings of this study has answered all three research questions with favourable responses.

\section{Funding and acknowledgement}

This research is supported by grant 2016-0097-106-04 from the National Child Development Research Centre in 2017. 


\section{References}

Anderson, L. W., Krathwohl, D. R., Airasian, P. W., Cruikshank, K. A., Mayer, R. E., Pintrich, P. R., Raths, J., \& Wittrock, M. C. (Eds.). (2000). A taxonomy for learning, teaching, and assessing: A revision of Bloom's taxonomy of educational objectives. Longman.

Ayob, A., Hussain, A., Marzuki Mustafa, M., \& Fauzi Aminuddin Shazi Shaarani, M. (2011). Nurturing creativity and innovative thinking through experiential learning. Procedia: Social and Behavioral Sciences, 18, 247-254. https://doi.org/10.1016/j.sbspro.2011.05.035

Brunkalla, K. (2009). How to increase mathematical creativity - An experiment. The Mathematics Enthusiast, 6(1), 257-266.

Chamberlin, S. A., \& Moon, S. M. (2005). Model eliciting activities as a tool to develop and identify creatively gifted mathematicians. The Journal of Secondary Gifted Education, 17(1), 37-47. https://doi.org/10.4219/jsge-2005-393

Costa, A. L. (Ed.). (2001). Developing minds: A resource book for teaching thinking. Alexandria: Association for Supervision and Curriculum Development.

Ellwood, S., Pallier, G., Snyder, A., \& Gallette, J. (2009). The incubation effect: Hatching a solution? Creativity Research Journal, 21(1), 6-14. https://doi.org/10.1080/10400410802633368

Fard, A. E., Bahador, A., Moghadam, M. N., Rajabi, H., \& Moradi, A. N. (2014). The possible impact of problem-solving method of instruction on exceptional students' creativity. Journal of Education and Training Studies, 2(3), 60-68. https://doi.org/10.11114/jets.v2i3.342

Greeno, J. G. (2017). Forms of understanding in mathematical problem solving. Taylor \& Francis. https://doi.org/10.4324/9781315188522-5

Griethuijsen, van R. A. L. F., Eijck, van M. W., Haste, H., Brok, den P. J., Skinner, N. C., Mansour, N., Savran Gencer, A., \& BouJaoude, S. (2014). Global patterns in students' views of science and interest in science. Research in Science Education, 45(4), 581-603. https://doi.org/10.1007/s11165-014-9438-6

Guilford, J. P. (1967). Creativity: Yesterday, today and tomorrow. The Journal of Creative Behavior, 1(1), 3-14. https://doi.org/10.1002/j.2162-6057.1967.tb00002.x

Haylock, D. W. (1987). A framework for assessing mathematical creativity in schoolchildren. Educational Studies in Mathematics, 18(1), 59-74. https://doi.org/10.1007/BF00367914

$\mathrm{Hu}, \mathrm{R}$., Xiaohui, S., \& Shieh, Ch. J. (2017). A study on the application of creative problem solving teaching to statistics teaching. EURASIA: Journal of Mathematics, Science and Technology Education, 13(7), 3139-3149. https://doi.org/10.12973/eurasia.2017.00708a

Isoda, M. (2010). Lesson study: Problem solving approaches in mathematics education as a Japanese experience. Procedia: Social and Behavioral Sciences, 8, 17-27.

https://doi.org/10.1016/j.sbspro.2010.12.003

James, M. A. (2015). Managing the classroom for creativity. Creative Education, 6, 1032-1043. https://doi.org/10.4236/ce.2015.610102

Kaplan, D. E. (2019). Creativity in education: Teaching for creativity development. Psychology, 10, 140-147. https://doi.org/10.4236/psych.2019.102012

Kaufman, J. C., \& Sternberg, R. J. (Eds.). (2006). The international handbook of creativity. Cambridge University Press. https://doi.org/10.1017/CBO9780511818240

Khalid, M. (2017). Fostering problem solving and performance assessment among Malaysian mathematics teachers. Sains Humanika, 9(1-2), 51-55. https://doi.org/10.11113/sh.v9n1-2.1098 
Kim, K. H. (2006). Can we trust creativity tests? A review of the Torrance Tests of Creative Thinking (TTCT). Creativity Research Journal, 18(1), 3-14. https://doi.org/10.1207/s15326934crj1801_2

Kopka, J. (2010). How to solve mathematical problems. Catholic University in Ružomberok. Ružomberok, Slovakia [unpublished source].

Lesh, R., \& Zawojewski, J. S. (2007). Problem solving and modelling. In Jr. F. K. Lester (Ed.), Second handbook for research on mathematics teaching and learning (pp. 763-802). Information Age Publishing.

Lester, F. K. Jr., Masingila, J. O., Mau, S. T., Lambdin, D. V., Santon, dos V. M., \& Raymond, A. M. (1994). Learning how to teach via problem solving. In D. B. Aichele \& A. F. Coxford (Eds.), Professional development for teachers of mathematics (pp. 152-166). National Council of Teachers of Mathematics.

Levenson, E. (2013). Tasks that may occasion mathematical creativity: Teachers' choices. Journal of Mathematics Teacher Education, 16(4), 269-291. https://doi.org/10.1007/s10857-012-9229-9

Liljedahl, P., \& Sriraman, B. (2006). Musings on mathematical creativity. For the Learning of Mathematics, 26(1), 17-19.

Lim, Ch. S. (2010). Assessment in Malaysian school mathematics: Issues and concerns. http://www.criced. tsukuba.ac.jp/math/apec/apec2009/doc/pdf_20-21/LimChapSam-paper.pdf

Mann, E. L. (2006). Creativity: The essence of mathematics. Journal for the Education of the Gifted, 30(2), 236-262. https://doi.org/10.4219/jeg-2006-264

Mellou, E. (1996). Can creativity be nurtured in young children? Early Child Development and Care, 119(1), 119-130. https://doi.org/10.1080/0300443961190109

Ministry of Education, Malaysia. (2013). Malaysia educational blueprint: Annual report 2013. https://www. padu.edu.my/wp-content/uploads/2018/01/PADU-AR-2013-ENG.pdf

National Council of Teachers of Mathematics. (2000). Executive summary: Principles and standards for school mathematics. https://www.nctm.org/uploadedFiles/Standards_and_Positions/PSSM_ExecutiveSummary.pdf

Novak, J. D. (2010). Learning, creating and using knowledge: Concept maps as facilitative tools in schools and corporations. Routledge. https://doi.org/10.4324/9780203862001

OECD. (2013). PISA 2012 assessment and analytical framework: Mathematics, reading, science, problem solving and financial literacy. https://www.oecd-ilibrary.org/docserver/9789264190511-en.pdf?exp ires $=1580654526 \& \mathrm{id}=\mathrm{id} \& \mathrm{accname}=$ guest $\&$ checksum $=074 \mathrm{~EB} 03 \mathrm{FD} 4 \mathrm{D} 7 \mathrm{FB} 122 \mathrm{~A} 322 \mathrm{C} 1 \mathrm{AB} 81 \mathrm{~A} 10 \mathrm{BD}$

OECD. (2014a). Education at a Glance 2014: Highlights. https://www.oecd-ilibrary.org/docserver/eag highlights-2014-en.pdf?expires $=1580644839 \&$ \&id=id\&accname $=$ guest $\&$ checksum $=4$ F347DD90BB 5080FB66B3D588B605058

OECD. (2014b). PISA 2012 results in focus: What 15-year-olds know and what they can do with what they know. https://www.oecd.org/pisa/keyfindings/pisa-2012-results-overview.pdf

OECD. (2014c). PISA 2012 results: Creative problem solving. Students' skills in tackling real-life problems. Vol. V. https://www.oecd-ilibrary.org/docserver/9789264208070-en.pdf?expires=1580659048\&id=i $\mathrm{d} \&$ accname $=$ guest $\&$ checksum $=43503$ BB658FB2794E8280D794380E28E

OECD. (2014d). PISA 2012 technical report. http://www.oecd.org/pisa/pisaproducts/PISA-2012-technical-report-final.pdf

Park, M. (2013). Korean primary school teachers' conceptions of foundations and creativity in mathematics. Korean Society of Mathematical Education (Series A: The Mathematical Education), 52(3), 399-422. https://doi.org/10.7468/mathedu.2013.52.3.399 
Plucker, J. A., Beghetto, R. A., \& Dow, G. T. (2004). Why isn't creativity more important to educational psychologists? Potentials, pitfalls, and future directions in creativity research. Educational Psychologist, 39(2), 83-96. https://doi.org/10.1207/s15326985ep3902_1

Polya, G. (2004). How to solve it: A new aspect of mathematical method. Series: Princeton Science Library. Princeton University Press.

Posamentier, A. S., Smith, B. S., \& Stepelman, J. (2009). Teaching secondary mathematics: Teaching and enrichments units. Merrill Prentice Hall.

Retalis, S., Katsamani, M., Georgiakakis, P., Lazakidou, G., Petropoulou, O., \& Kargidis, Th. (2010). Designing collaborative learning sessions that promote creative problem solving using design patterns. In L. Dirckinck-Holmfeld, V. Hodgson, Ch. Jones, M. de Laat, D. McConnell, \& Th. Ryberg (Eds.), Proceedings of the $7^{\text {th }}$ International Conference on Networked Learning (pp. 490-498), 3-4 May, 2010. Aalborg, Denmark.

Robinson, K. (2006). Do schools kill creativity? TED: Ideas worth Spreading. https://www.ted.com/talks/ sir_ken_robinson_do_schools_kill_creativity

Robinson, K., \& Aronica, L. (2015). Creative schools: The grassroots revolution that's transforming education. Penguin Books.

Runco, M. A., \& Johnson, D. J. (2002). Parents' and teachers' implicit theories of children's creativity: A cross-cultural perspective. Creativity Research Journal, 14(3-4), 427-438. https://doi.org/10.1207/S15326934CRJ1434_12

Saleh, S., \& Aziz, A. (2012). Teaching practices among secondary school teachers in Malaysia. https://pdfs.semanticscholar.org/37a7/b40e50d9ab5eaf66e8abfcdebee4761ac9b9.pdf? $\mathrm{ga}=2.20604029 .454579747 .1580658915-199233841.1528889777$

Silver, E. A. (1997). Fostering creativity through instruction rich in mathematical problem solving and problem posing. ZDM: Mathematics Education, 29(3), 75-80. https://doi.org/10.1007/s11858-997-0003-x

Sriraman, B. (2004). The characteristics of mathematical creativity. The Mathematics Educator, 14(1), 19-34.

Sriraman, B. (2005). Are giftedness and creativity synonyms in mathematics? The Journal of Secondary Gifted Education, 17(1), 20-36. https://doi.org/10.4219/jsge-2005-389

Sternberg, R. J. (2006). The nature of creativity. Creativity Research Journal, 18(1), 87-98. https://doi.org/10.1207/s15326934crj1801_10

Sternberg, R. J. (2012). The assessment of creativity: An investment-based approach. Creativity Research Journal, 24(1), 3-12. https://doi.org/10.1080/10400419.2012.652925

Teo, L. K. C., \& Waugh, R. F. (2010). A Rasch measure of fostering creativity. Creativity Research Journal, 22(2), 206-218. https://doi.org/10.1080/10400419.2010.481534

Torrance, E. P. (1971). Are the Torrance tests of creative thinking biased against or in favor of "Disadvantaged” groups? Gifted Child Quarterly, 15(2), 75-80. https://doi.org/10.1177/001698627101500201

Trawick-Smith, J. (2014). Early childhood development: A multicultural perspective. Pearson Education Limited. 


\section{Appendix}

The mapping of research objectives to the data type, data collection, validity criteria and data analysis (source: created by authors)

\begin{tabular}{|c|c|c|c|c|c|}
\hline Research objective & $\begin{array}{l}\text { Research } \\
\text { questions }\end{array}$ & Data type & $\begin{array}{c}\text { Data collection } \\
\text { strategy }\end{array}$ & Validity & $\begin{array}{c}\text { Data } \\
\text { analysis }\end{array}$ \\
\hline $\begin{array}{l}\text { To examine the } \\
\text { changes in chil- } \\
\text { dren's creativity } \\
\text { before and after } \\
\text { intervention using } \\
\text { Torrance Test of } \\
\text { Creative } \\
\text { Thinking }\end{array}$ & $\begin{array}{l}\text { Are there differ- } \\
\text { ences in children's } \\
\text { creativity after } \\
\text { intervention, as } \\
\text { measured through } \\
\text { the Torrance Test } \\
\text { of Creative Think- } \\
\text { ing? }\end{array}$ & $\begin{array}{l}\text { Quantitative } \\
\text { Qualitative }\end{array}$ & $\begin{array}{l}\text { Torrance Test } \\
\text { of Creative } \\
\text { Thinking (pre- } \\
\text { and post-) } \\
\text { Interview }\end{array}$ & $\begin{array}{l}\text { Triangulation } \\
\text { member } \\
\text { check } \\
\text { prolonged } \\
\text { engagement }\end{array}$ & $\begin{array}{l}\text { Statistical - } \\
\text { t-test } \\
\text { Theme } \\
\text { searching }\end{array}$ \\
\hline $\begin{array}{l}\text { To examine } \\
\text { changes in } \\
\text { children's en- } \\
\text { hancement in } \\
\text { mathematical } \\
\text { problem-solving } \\
\text { as a result of the } \\
\text { intervention. }\end{array}$ & $\begin{array}{l}\text { What are the } \\
\text { changes in chil- } \\
\text { dren's mathemati- } \\
\text { cal problem-solv- } \\
\text { ing ability after } \\
\text { intervention? }\end{array}$ & Quantitative & $\begin{array}{l}\text { Program for } \\
\text { International } \\
\text { Student Assess- } \\
\text { ment problem } \\
\text { solving test. } \\
\text { Classwork } \\
\text { video tape (ob- } \\
\text { servation) } \\
\text { Interview }\end{array}$ & $\begin{array}{l}\text { Triangulation } \\
\text { member } \\
\text { check } \\
\text { prolonged } \\
\text { engagement }\end{array}$ & $\begin{array}{l}\text { Statistical } \\
\text {-t-tests, } \\
\text { analysis of } \\
\text { covariance } \\
\text { Theme } \\
\text { searching }\end{array}$ \\
\hline $\begin{array}{l}\text { To investigate } \\
\text { the relationship } \\
\text { between creativity } \\
\text { and problem-solv- } \\
\text { ing ability after } \\
\text { learning through } \\
\text { creative problem } \\
\text { solving }\end{array}$ & $\begin{array}{l}\text { Is there any rela- } \\
\text { tionship between } \\
\text { creativity and } \\
\text { problem-solving } \\
\text { ability after learn- } \\
\text { ing through } \\
\text { creative problem } \\
\text { solving? }\end{array}$ & Quantitative & $\begin{array}{l}\text { Torrance Test } \\
\text { of Creative } \\
\text { Thinking and } \\
\text { Program for } \\
\text { International } \\
\text { Student Assess- } \\
\text { ment problem } \\
\text { solving test }\end{array}$ & $\begin{array}{l}\text { Triangulation } \\
\text { member } \\
\text { check } \\
\text { prolonged } \\
\text { engagement }\end{array}$ & $\begin{array}{l}\text { Statistical } \\
\text { correlation } \\
\text { and regres- } \\
\text { sion }\end{array}$ \\
\hline
\end{tabular}

\section{KÜRYBIŠKUMO STIPRINIMAS IR PROBLEMŲ SPRENDIMO GEBĖJIMAI, KŪRYBIŠKAI SPRENDŽIANT MATEMATIKOS MOKYMO PROBLEMAS}

\section{Madihah KHALID, Supiah SAAD, Siti Rafiah ABDUL HAMID, Muhammad RIDHUAN ABDULLAH, Hasniza IBRAHIM, Masitah SHAHRILL}

\section{Santrauka}

Pastaraisiais metais suaktyvejo raginimai ugdyti kūrybiškumą ir jo mokyti nuo pat mažumès. Kūrybiškumas yra ịprastas mokant meninių dalykų, tačiau nèra pastebimas bruožas mokant mokslinių, technologinių, inžinerinių ir matematinių disciplinų. Tačiau iš tiesų svarbu tai, kaip mokoma tam tikro dalyko. Šio tyrimo tikslas - skatinti kūrybiškumą matematikos mokymo pavyzdžiu, kai kūrybiškai sprendžiamos problemos, ir tai atitinkamai apibrèžiama. Šiame kvazieksperimentiniame tyrime nagrinėjami pokyčiai, susiję su tuo, kaip moksleiviai mokosi matematikos, 
kūrybiškai spręsdami problemas. Iš viso tyrime dalyvavo 172 pirmosios formos moksleiviai, priklausantys stebejimo ir lyginimo grupems iš keturių mokyklų, esančių Gombako rajono teritorijoje (Malaizija). Buvo surinkti mišrūs kokybiniai ir kiekybiniai duomenys, siekiant ištirti realizuotus tris ciklus pamokų, skirtų kūrybiniams problemų sprendimams. Buvo naudojamasi šiomis priemonemis: Torrance'o kūrybinio mąstymo testu, matematinių problemų sprendimo testu ir kūrybiškumo rezultatų vertinimo kontroliniu sąrašu. Straipsnyje pristatomi tik kiekybiniai duomenys. Rezultatai atskleidžia statistiškai reikšmingą padidejjimą vertinant kūrybiškumą daugelyje kategorijų ir pasitelkiant problemų sprendimo testus. Šiame tyrime dalyvavo mokytojai ir tyrejai, atlikti kūrybinio problemų sprendimo bandymai mokant matematikos ir stengiantis ugdyti moksleivių kūrybinį mąstymą bei problemų sprendimo gebejimus. Tai atitinka Kurikulum Standard Sekolah Menengah ịvadinę dalị, iš naujo pabrèžiant mokslinị, technologinị, inžinerinị ir matematinị ugdymą apskritai, šiose srityse akcentuojant aukštesnio lygio pertvarkytą mąstyseną.

Reikšminiai žodžiai: kūrybiškumo testas, kūrybiškumas matematikoje, gebejiimo spręsti problemas ugdymas, matematikos mokymasis sprendžiant problemas, pamokos tyrimas, Kurikulum Standard Sekolah Menengah naujas planas. 